Clemson University

TigerPrints

12-2017

Supporting the Supporters: Professional Development for Science Coordinators

Brooke A. Whitworth

Randy L. Bell

Jennifer L. Maeng

Amanda L. Gonczi

Follow this and additional works at: https://tigerprints.clemson.edu/teach_learn_pub

Part of the Science and Mathematics Education Commons 


\section{Journal of Science Teacher Education}

\section{Supporting the Supporters: Professional Development for Science Coordinators}

\section{Brooke A. Whitworth, Randy L. Bell, Jennifer L. Maeng \& Amanda L. Gonczi}

To cite this article: Brooke A. Whitworth, Randy L. Bell, Jennifer L. Maeng \& Amanda L. Gonczi (2017): Supporting the Supporters: Professional Development for Science Coordinators, Journal of Science Teacher Education

To link to this article: https://doi.org/10.1080/1046560X.2017.1404814

View supplementary material $\circlearrowright$

曲 Published online: 04 Dec 2017.

Submit your article to this journal 주

Q View related articles $\square$

View Crossmark data ¿ 


\title{
Supporting the Supporters: Professional Development for Science Coordinators
}

\author{
Brooke A. Whitworth $\mathbb{1}^{a}$, Randy L. Bell ${ }^{b}$, Jennifer L. Maeng $\mathbb{1}^{c}$, and Amanda L. Gonczi ${ }^{\mathrm{d}}$

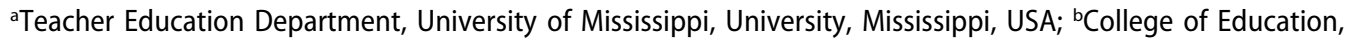 \\ Oregon State University, Corvallis, Oregon, USA; 'Curry School of Education, University of Virginia, \\ Charlottesville, Virginia, USA; 'Great Lakes Research Center, Michigan Technological University, Houghton, \\ Michigan, USA.
}

\begin{abstract}
We investigated changes in district science coordinators' understandings and practices following their participation in a statewide professional development (PD). Participants included 13 male and 34 female science coordinators from 42 different school districts in Virginia. Data included presurvey, postsurvey, and delayed postsurvey responses; follow-up interviews; and observations of the PD and of science coordinators at work in their district. Results indicated that science coordinator understandings about pedagogy and job responsibilities changed following the PD and were aligned with the goals of PD. However, coordinators' practices following PD did not fully reflect their understandings about pedagogy. Results suggest that PD aligned with a situated learning framework, specifically the components of collaboration and authentic context, supports coordinators in changing their understandings and some of their practices.
\end{abstract}

\section{KEYWORDS}

district leadership; professional development; science coordinators

School districts bear the brunt of providing professional development (PD) to improve teaching and learning (Corcoran, Fuhrman, \& Belcher, 2001), spending billions of dollars on PD for their teachers each year (Birman et al., 2007; Pianta, 2011; Wilson, 2013). PD is essential for improving in-service science teachers' understandings and practices in order to meet the needs of new science education reform efforts and ultimately improve student understanding (Hewson, 2007). But any assumption that the influence of PD on teaching, learning, and student achievement is straightforward is a naïve assumption. The complicated nature of using PD to ultimately improve student understanding is depicted in Figure 1.

A vast amount of research focuses on the bottom three layers of Figure 1 (Desimone, 2009; Whitworth, 2014; Yoon, Duncan, Lee, Scarloss, \& Shapley, 2007); however, there is very little research focused on the top three steps of the figure (Kennedy, 2016; Luft \& Hewson, 2014; Whitworth, Maeng, Wheeler, \& Chiu, 2017). This study begins to determine what diminishes the impact of PD as it trickles down to teachers and students by studying how PD designed specifically for science coordinators impacts science coordinator understandings and practices (see Figure 1).

CONTACT Brooke A. Whitworth bawhit@olemiss.edu Q Teacher Education Department, University of Mississippi, P.O. Box 1848, University, MS 38677, USA.

(1) Supplemental data for this article can be accessed from the publisher's website. 


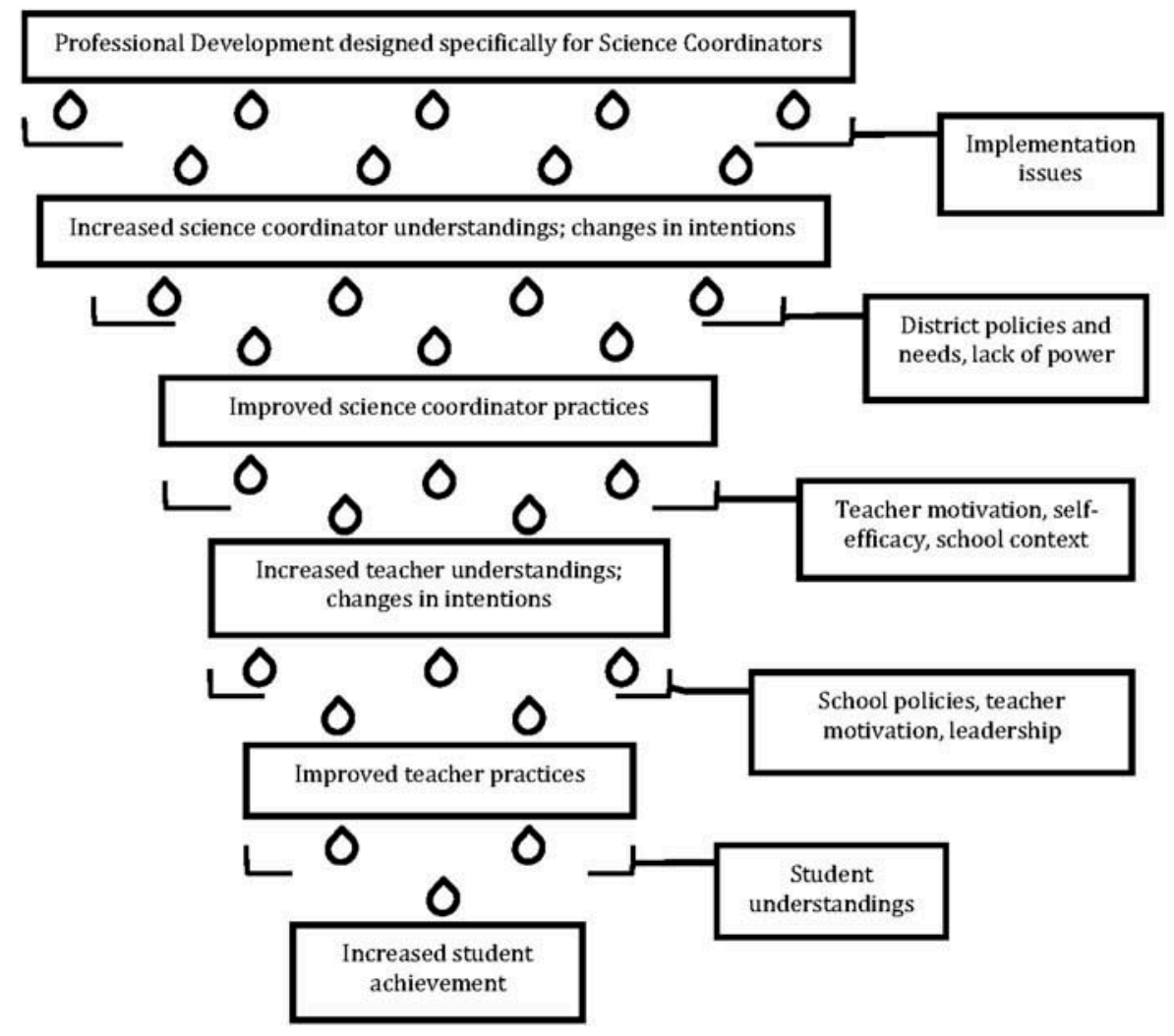

Figure 1. An illustration of the diminishing systematic impact of professional development for science coordinators on increasing student achievement.

Effectiveness in improving teaching and learning is largely dependent on the decisions of district administrators and instructional specialists, including science, math, and testing coordinators (Firestone, Mangin, Martinez, \& Plovsky, 2005). Furthermore, these instructional specialists play an important role in molding standards as they support teachers in interpreting and implementing a new curriculum (Domina, Lewis, Agarwal, \& Hanselman, 2015). As countries, states, and districts adopt new standards, instructional specialists are the administrators who work most closely with teachers (Lipsky, 1983) and create educational policies as they work with teachers to bring these standards into classrooms. Between 1997-1998 and 2012-2013 the number of instructional specialists per 1,000 U.S. students doubled, and the number of districts without an instructional specialist decreased from $20 \%$ to $7 \%$ (Domina et al., 2015). Given the influence of these administrators on improving teaching and learning and adopting new standards, further investigation of the specialist role and the support these individuals receive is warranted (Luft \& Hewson, 2014; Whitworth \& Chiu, 2015).

In science education, researchers often identify instructional specialists as science coordinators, science supervisors, or science specialists (Whitworth et al., 2017). For the purposes of this study, we identify these individuals as science coordinators and define this role as a district administrator who usually holds at least a master of education degree and 
is experienced in the classroom (Edmondson, Sterling, \& Reid, 2012). In most districts, the science coordinator is responsible for overseeing PD for science teachers and the development of the science curriculum. As early as 1966 Reinisch advocated for the science coordinator position as he identified the need for science consultants at the elementary level. Beinsenherz and Yager (1991) asserted that a strong science supervisor has the ability to increase the commitment to science education. As coordinators can have a significant impact on a district's effectiveness, it is critical for these individuals to have the support and time necessary to fulfill this role (Beinsenherz \& Yager, 1991). Yet little is known about science coordinators, the PD they receive, and the supports they need in their work (Kennedy, 2016; Luft \& Hewson, 2014; Whitworth et al., 2017).

Thus, the current study examines PD designed specifically for science coordinators within the context of a statewide program in a mid-Atlantic state aimed at building an infrastructure to support sustained, intensive science teacher PD to increase student achievement. In order to build this infrastructure, the program provided PD opportunities for different groups of educators, including an Elementary Institute for in-service elementary teachers (Grades 4-6) and a Science Coordinator Academy (SCA). Both components of the PD focused on problem-based learning (PBL), inquiry, and nature of science (NOS) instruction as reforms-based practices that have been shown to increase student achievement (e.g., Akerson \& Abd-El-Khalick, 2003; Duschl, Schweingruber, \& Shouse, 2007; Hmelo-Silver, 2004; National Commission on Mathematics and Science Teaching for the 21st Century, 2000; National Research Council [NRC], 1996; Stepien \& Gallagher, 1993). This study focuses on SCA, PD specifically designed for science coordinators. In the sections that follow, the conceptual framework and literature on district science coordinators and high-quality science instruction are reviewed.

\section{Conceptual framework}

Situated learning theory suggests that knowledge is created as individuals interact with their environment to achieve a goal (McLellan, 1996). It recognizes learning as a situated and contextualized process that occurs continuously. The individual and the context are not separate but influence and change (or construct) each other (McLellan, 1996). Furthermore, the context includes the physical, social, ethical, and historical norms affecting how people interact with the objects in their environment and with one another. McLellan (1996) identified key components of a situated learning model as reflection, cognitive apprenticeship, collaboration, coaching, opportunities for multiple practice, and the articulation of learning skills. Table 1 defines these components and provides strategies for integrating these components into PD. The present investigation is the first, to our knowledge, to explore the effectiveness of a PD program designed specifically for district coordinators aligned with situated learning theory.

Research suggests a clear consensus regarding key characteristics of PD associated with changes in teacher learning, classroom practices, and student achievement (Desimone, 2009). These key characteristics include a content focus, active learning, coherence, duration, and collective participation (e.g., Garet, Porter, Desimone, Birman, \& Yoon, 2001; Loucks-Horsley, Stiles, Mundry, Love, \& Hewson, 2010). This perspective serves as the conceptual framework and aligns well with situated learning theory (see Table 2). 
Table 1. Situated learning components and strategies for implementation.

\begin{tabular}{|c|c|c|}
\hline Component & Definition & Strategies \\
\hline Reflection & $\begin{array}{l}\text { Students consider what they have learned } \\
\text { and integrate it with their own experiences. }\end{array}$ & $\begin{array}{l}\text { Process time, think-share-pair, written } \\
\text { reflections }\end{array}$ \\
\hline Cognitive apprenticeship & $\begin{array}{l}\text { Students participate in authentic practices in } \\
\text { authentic contexts. }\end{array}$ & Work with and shadow experts in the field \\
\hline Collaboration & $\begin{array}{l}\text { Students construct their knowledge through } \\
\text { social interactions. }\end{array}$ & $\begin{array}{l}\text { Collective problem solving, opportunity to } \\
\text { take on multiple roles, developing group } \\
\text { skills }\end{array}$ \\
\hline Coaching & $\begin{array}{l}\text { The instructor guides student learning rather } \\
\text { than providing direct instruction. }\end{array}$ & $\begin{array}{l}\text { Active learning opportunities, hands-on } \\
\text { activities }\end{array}$ \\
\hline $\begin{array}{l}\text { Opportunities for } \\
\text { multiple practice }\end{array}$ & $\begin{array}{l}\text { Students receive repeated opportunities to } \\
\text { practice and develop skills. }\end{array}$ & $\begin{array}{l}\text { Repeated practice of skills when learning } \\
\text { new content in authentic context }\end{array}$ \\
\hline $\begin{array}{l}\text { Articulation of learning } \\
\text { skills }\end{array}$ & $\begin{array}{l}\text { Students articulate their thinking, knowledge, } \\
\text { reasoning, and problem-solving processes. }\end{array}$ & $\begin{array}{l}\text { Discussions, journal writing, teaching what } \\
\text { they have learned }\end{array}$ \\
\hline
\end{tabular}

Table 2. Relationship between the components of SCA, the situated learning model, and characteristics of effective PD.

\begin{tabular}{|c|c|c|}
\hline Component of SCA & $\begin{array}{l}\text { Alignment with situated } \\
\text { learning model }\end{array}$ & $\begin{array}{c}\text { Alignment with characteristics of } \\
\text { effective PD }\end{array}$ \\
\hline $\begin{array}{l}\text { Problem-based learning, inquiry, nature of } \\
\text { science activities }\end{array}$ & $\begin{array}{l}\text { Cognitive apprenticeship } \\
\text { Collaboration } \\
\text { Coaching }\end{array}$ & $\begin{array}{l}\text { Active learning } \\
\text { Coherence } \\
\text { Content focus } \\
\text { Collective participation }\end{array}$ \\
\hline Evaluating teaching practices & $\begin{array}{l}\text { Cognitive apprenticeship } \\
\text { Coaching }\end{array}$ & $\begin{array}{l}\text { Active learning } \\
\text { Coherence } \\
\text { Collective participation }\end{array}$ \\
\hline Using data to inform decisions & $\begin{array}{l}\text { Reflection } \\
\text { Authentic context } \\
\text { Opportunities for multiple } \\
\text { practice }\end{array}$ & $\begin{array}{l}\text { Active learning } \\
\text { Coherence } \\
\text { Duration }\end{array}$ \\
\hline Strategic plan development & $\begin{array}{l}\text { Reflection } \\
\text { Authentic context } \\
\text { Opportunities for multiple } \\
\text { practice } \\
\text { Coaching }\end{array}$ & $\begin{array}{l}\text { Active learning } \\
\text { Coherence } \\
\text { Content focus }\end{array}$ \\
\hline PD instructor's role & $\begin{array}{l}\text { Cognitive apprenticeship } \\
\text { Articulation of learning skills } \\
\text { Coaching }\end{array}$ & $\begin{array}{l}\text { Coherence } \\
\text { Content focus } \\
\text { Duration }\end{array}$ \\
\hline $\begin{array}{l}\text { Attending with individuals with same job } \\
\text { responsibilities }\end{array}$ & $\begin{array}{l}\text { Authentic context } \\
\text { Collaboration }\end{array}$ & $\begin{array}{l}\text { Coherence } \\
\text { Collaborative participation }\end{array}$ \\
\hline
\end{tabular}

Note. SCA = Science Coordinator Academy; PD = professional development.

\section{District science coordinators}

The literature on science coordinators is meager. Currently, there is a need to better understand the role of science coordinators, the support coordinators receive themselves, coordinators' views of $\mathrm{PD}$, and areas in which coordinators need $\mathrm{PD}$ to support high-quality science instruction (Kennedy, 2016; Luft \& Hewson, 2014). Past research on science coordinators (Perrine, 1984) has identified two main components as critical to supervisory effectiveness: (a) providing teachers with content and pedagogical supports and (b) effective communication with teachers. Perrine (1984) suggested that coordinators provide teachers with content knowledge and respond proactively to teachers' needs. By meeting teacher needs, administrators in subject area supervisory positions are perceived by other stakeholders as having a high impact on the improvement of instruction (Tracy, 1993). 
Despite this perception of coordinators, research suggests that coordinators may not have a complete and/or accurate view of effective PD (Rogers et al., 2007); consequently, the PD offered by coordinators may not be effective. In one study, coordinators identified active learning, collaboration, and a content focus as important aspects of PD (Rogers et al., 2007), but did not identify the importance of duration, collective participation, or coherence in the design of effective PD. Thus, these definitions did not fully encompass the characteristics of effective PD identified in the literature (e.g., Desimone, 2009; Hewson, 2007; Loucks-Horsley et al., 2010).

Other studies suggest that the leadership provided by district-level staff is critical for increasing student achievement (Copeland \& Knapp, 2006; Honig, 2006). Because coordinators can have a significant impact on a district's effectiveness, it is important that these individuals have the support and time necessary to fulfill this role (Beinsenherz \& Yager, 1991). Thus, there is still a need to better understand the role of science coordinators, the $\mathrm{PD}$ they receive, the views of $\mathrm{PD}$ they hold, and the areas in which they need PD to support high-quality science instruction.

\section{High-quality science instructional approaches}

Hands-on, student-centered instructional approaches have been the focus of recent reforms-based documents (NRC, 2012; NGSS Lead States, 2013). A plethora of PD has focused on supporting teachers in transforming their lecture-based, teacher-centered classrooms to active, engaging, student-centered classrooms (Duschl et al., 2007; NRC, 1996; Wilson, 2013). A variety of reforms-based instructional approaches, such as PBL, inquiry-based instruction, and NOS, have been recommended as effective for helping teachers create this type of classroom environment (Hmelo-Silver, 2004; NRC, 1996, 2012). We acknowledge that many instructional approaches and components can characterize high-quality science instruction, but we focus on these three as the focus of the PD under study. Within this PD, PBL was viewed as the context through which authentic science problems could be investigated through inquiry-based and explicit NOS instruction (see Figure 2). Science coordinators need to have a solid understanding of these approaches in order to effectively educate and support teachers in implementing these strategies.

PBL is an approach in which students work collaboratively to research and solve a realworld science problem (Hmelo-Silver, 2004; Sterling, 2007). Activating student interests and addressing student needs is crucial for PBL instruction to be effective (Sterling, 2007; Sterling \& Frazier, 2006). Implementing PBL has the potential to engage students in active, inquiry-based learning; increase achievement and content understanding; and provide an opportunity to engage the community in student learning (Hmelo-Silver, 2004; Sterling \& Frazier, 2006; Sterling, Matkins, Frazier, \& Logerwell, 2007). Teachers perceive the implementation of PBL as difficult and encounter barriers in implementation (e.g., Ertmer et al., 2009; Fryckholm, 2004; Hmelo-Silver, 2004). Consequently, it is essential for teachers to be supported in the process of implementing PBL. Coordinators themselves may struggle with knowing how to guide and support teachers; receiving PD about PBL may aid them in this endeavor.

Inquiry is an important component of science instruction that aids students in developing scientific literacy and allows them to engage in scientific practices (NGSS Lead 


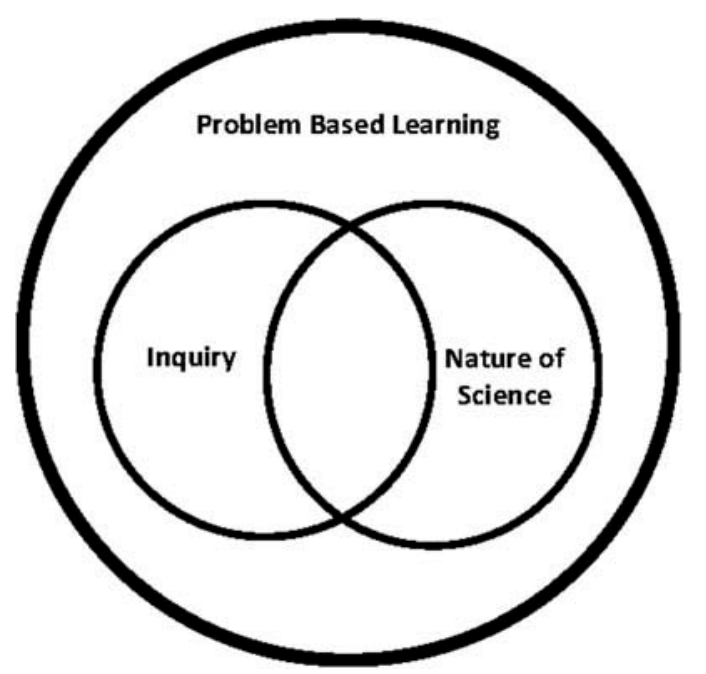

Figure 2. Relationship between problem-based learning, inquiry-based instruction, and nature of science.

States, 2013). Simply, inquiry is defined as a process in which students answer scientific research questions through data analysis (Bell, Smetana, \& Binns, 2005). In implementing inquiry, it is important for teachers to scaffold instruction so students have opportunities to develop the necessary skills and understandings to design and conduct investigations (Peters, 2009). Inquiry instruction should also integrate and appropriately address instructional objectives (Luft, Bell, \& Gess-Newsome, 2008). Inquiry-based learning can lead to improvements in students' science understandings and achievement (e.g., Bransford, Brown, \& Cocking, 2000); thus, it is considered a high-quality science instructional approach. However, teachers often encounter barriers in their attempts to implement inquiry in the classroom (Anderson, 2002; Keys \& Bryan, 2001). Thus, supporting teachers in implementing inquiry in the classroom and developing their understandings around inquiry is crucial. Coordinators also need in-depth knowledge about inquiry and the skills needed to support their teachers in the implementation of inquiry.

A vital component of scientific literacy is NOS (Bybee, 1997). NOS comprises tenets for exploration (NGSS Lead States, 2013) and refers to science as a way of knowing. There are a variety of views on what constitutes NOS, but some tenets are agreed on as appropriate for kindergarten-Grade 12 teaching (e.g., Lederman, 2007; NGSS Lead States, 2013): Scientific knowledge is based on evidence, scientific knowledge is both reliable and tentative, scientific knowledge is based on both observations and inferences, creativity is involved in the creation of scientific knowledge, scientific laws and theories are different kinds of knowledge, many methods are involved in the development of scientific knowledge, and scientific knowledge is subjective. Research indicates that explicit instruction around NOS with reflective discussions may be effective in helping students develop appropriate understandings of NOS (e.g., Abd-El-Khalick, Bell, \& Lederman, 1998; Akerson \& Hanuscin, 2007). NOS instruction helps students understand the big picture of what science is and how it works, encouraging broader reforms in science education with the goal of high-quality science instruction (NGSS Lead States, 2013). 
Often teachers hold deficient views of NOS (e.g., Akerson, Morrison, \& McDuffie, 2006; Tsai, 2002) and struggle with integrating NOS into classroom instruction (Abd-ElKhalick, Bell, \& Lederman, 1998; Bell, Lederman, \& Abd-El-Khalick, 2000). Even when they hold complete understandings, teachers appear to have difficulty transferring their understandings to practice (e.g., Abd-El-Khalick, Bell, \& Lederman, 1998; Akerson \& Abd-El-Khalick, 2003; Trumbull, Scrano, \& Bonney, 2006). Thus, it is reasonable to expect that coordinators may also struggle with understanding NOS and have difficultly supporting teachers working to integrate it into their instruction.

\section{Purpose}

The lack of research presently available on district science coordinators warrants further research on the interactions among coordinators' understandings, PD they receive and offer, and the role of district science coordinators. The purpose of this study was to investigate science coordinators' understandings and practices following their participation in SCA and to evaluate the effectiveness of SCA. Another purpose was to better understand the role a science coordinator plays in a school district by characterizing the support and PD provided by coordinators to teachers in their district. The following research questions guided this study:

(1) In what ways did science coordinators' understandings about reforms-based practices change following participation in SCA?

(2) In what ways did science coordinators perceive that their practices provided support for teachers in their districts after participating in SCA?

By exploring how science coordinators' understandings and practices change as a result of PD, we can begin to look at how coordinators provide support for teachers in their district and whether the PD they provide to teachers is aligned with SCA goals and instruction.

\section{Methods}

From within an interpretive paradigm (Erickson, 1986), an embedded concurrent mixedmethods design (Creswell \& Plano-Clark, 2011) was adopted to explore the understandings and practices of science coordinators. Within this design, quantitative and qualitative data were collected and analyzed throughout the study (see Figure 3). Descriptions of the context and coordinators are provided, followed by the data collection and analysis methods.

\section{SCA}

SCA occurred over 5 days and was facilitated by a team of six instructors. The 5 days were split into a fall 3-day session and a spring 2-day follow-up. During this time coordinators engaged in activities, presentations, and discussions moving them toward accomplishing the stated goals (Edmondson et al., 2012, p. 7): 


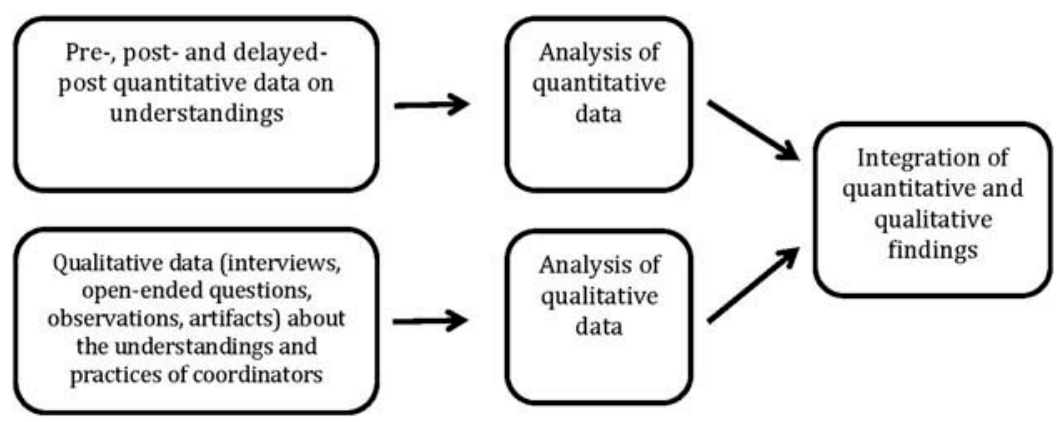

Figure 3. Research design.

(1) Learn to make improvements in leadership, teacher learning, quality teaching, and student learning.

(2) Develop a common understanding of inquiry, NOS, and PBL.

(3) Identify aspects of effective science teaching and learning.

(4) Compare district models of creating standards-based science curricula.

(5) Investigate data sources available to use to provide a focus to improve district science programs.

(6) Develop a science program strategic plan.

The first three goals targeted improving coordinators' understandings of inquiry, NOS, and PBL and how to implement these pedagogies in the classroom and in their districts. The last three goals focused on certain job responsibilities of coordinators and improving how coordinators understood and approached these responsibilities.

During SCA, each day began with an overview of the topics and concluded with a coordinator-written reflection. Opportunities for collaboration, reflection, and discussion were provided every day. Table 3 provides an overview of SCA and the corresponding objectives. In the months between the 3-day session in the fall and the 2-day session in the spring, coordinators worked on developing district strategic plans and engaged in reading resources provided. SCA instructors provided feedback to coordinators during this time and were available as needed. Instructors also provided coordinators with electronic access to all of the resources they used during SCA.

Table 3. Overview of the Science Coordinator Academy.

\begin{tabular}{|c|c|c|c|c|}
\hline Day 1 & Day 2 & Day 3 & Day 4 & Day 5 \\
\hline \multirow[t]{4}{*}{$\begin{array}{l}\text { Developing professional } \\
\text { development plans (1) }\end{array}$} & $\begin{array}{l}\text { Inquiry, problem-based } \\
\text { learning, and nature of } \\
\text { science (2) }\end{array}$ & $\begin{array}{l}\text { Data analysis to } \\
\text { evaluate science } \\
\text { programs (5) }\end{array}$ & $\begin{array}{l}\text { Strategic } \\
\text { planning (6) }\end{array}$ & $\begin{array}{l}\text { Analyzing student } \\
\text { work }(1,5)\end{array}$ \\
\hline & $\begin{array}{l}\text { Identifying effective teaching } \\
\text { (3) }\end{array}$ & $\begin{array}{l}\text { Assessing science } \\
\text { programs (5) }\end{array}$ & $\begin{array}{l}\text { Discourse and } \\
\text { misconceptions } \\
(1,3)\end{array}$ & $\begin{array}{l}\text { Aligning and } \\
\text { assessing } \\
\text { curriculum }(4,5)\end{array}$ \\
\hline & $\begin{array}{l}\text { Observation protocols for } \\
\text { effective science instruction } \\
(1,5)\end{array}$ & Strategic planning (6) & $\begin{array}{l}\text { Nature of science } \\
(2,3)\end{array}$ & Inquiry $(2,3)$ \\
\hline & Strategic planning (6) & & $\begin{array}{l}\text { Update from the } \\
\text { state }(5,6)\end{array}$ & $\begin{array}{l}\text { Strategic } \\
\text { planning (6) }\end{array}$ \\
\hline
\end{tabular}

Note. Corresponding objectives are in parentheses. 


\section{Participants}

Participants in this study included 47 individuals from the first three cohorts of SCA (see Table 4). Participants were from 42 different school districts in a mid-Atlantic state and ranged in age from 30 to 58 years. Participants' reported ethnicities were Asian $(n=1)$, African American $(n=5)$, and Caucasian $(n=41)$. All participants were in leadership positions in their respective school divisions, and $70 \%$ had experience leading science PD. Participants' administrative and/or supervision experience ranged from no experience to 13 years, and participants indicated that they had never attended PD designed specifically for science coordinators before.

\section{Data collection}

Data collection included surveys, interviews, and observations. This variety of data allowed for triangulation. Face and content validity for all surveys and interview protocols were supported through review by a panel of three experts in science education, evaluation, and measurement. All instruments underwent revision following each round of review until no further changes were needed.

\section{SCA perceptions surveys}

The purpose of the presurveys, postsurveys, and delayed postsurveys was to elicit coordinators' perceptions of their ability to evaluate and implement PD associated with PBL, NOS, and inquiry science instruction. The survey contained 14 Likert scale items and was administered as a presurvey, postsurvey, and delayed postsurvey (see Supplemental Material). The Likert scale ranged from 1 (not very proficient) to 5 (highly proficient). Nine of the 14 items assessed coordinators' understanding of and capacity to evaluate and implement PD associated with PBL, NOS, and inquiry science instruction. The other five Likert scale items assessed coordinators' proficiency in supporting research-based and standards-based science instruction, using data to improve district science programs, and

Table 4. Science Coordinator Academy participant demographic information $(N=47)$.

\begin{tabular}{lr}
\hline Characteristic & $n(\%)$ \\
\hline Gender & $34(72)$ \\
Female & $13(28)$ \\
Male & \\
Highest degree & $4(9)$ \\
Bachelor of arts or bachelor of science & $27(57)$ \\
Master of education or master of science & $7(15)$ \\
Doctor of education or doctor of philosophy in progress & $9(19)$ \\
Doctor of education or doctor of philosophy & $30(64)$ \\
Current position & $8(17)$ \\
District science coordinator or specialist & $9(19)$ \\
Science lead teacher or instructional coach & \\
Other & \\
Years in position & $22(47)$ \\
$0-2$ & $13(27)$ \\
$3-5$ & $6(13)$ \\
$6-7$ & $6(13)$ \\
$>7$ &
\end{tabular}

aPrincipals, central office administrators, beginning teacher advisors, department chair. 
developing a strategic plan for science education. The postsurvey was administered at the end of SCA; it contained four additional open-ended questions designed to elicit coordinators' perceptions of the quality of the SCA experience (see Supplemental Material). The pre- and post-SCA perceptions surveys were completed by $94 \%$ of coordinators.

One year after attending SCA, coordinators completed the delayed postsurvey on perceptions; $85 \%$ of coordinators responded. Overall, $83 \%$ completed all three surveys. In addition to the 14 Likert scale items on the pre-/postsurveys, the delayed postsurvey also included eight open-ended questions designed to elicit coordinators' perceptions of the effectiveness of SCA. It also ascertained perceptions of coordinators' experience a year later and how coordinators incorporated aspects of SCA into their practice (see Supplemental Material). Furthermore, it addressed how coordinators implemented concepts learned during SCA in their districts.

\section{Delayed post-SCA interviews}

Following the initial analysis of the delayed post-SCA survey, 13 coordinators (28\%) were purposefully selected to participate in a follow-up semistructured interview about their experiences during and following the academy (see Supplemental Material). Coordinators were selected based on their responses to the delayed postsurvey: low, medium, high, and no-change coordinators were selected. The interview protocol provided insight into how or whether coordinators utilized the training they received at SCA. The interviews lasted approximately $1 \mathrm{hr}$. Interviews were tape recorded and transcribed, and initial inferences and interpretations were added.

\section{Observations}

Four days (32 hr) of observations occurred during SCA and served to characterize activities coordinators participated in during SCA. Observations were made of activities, coordinators' engagement with the material, methods used by instructors to deliver instruction, the presence of characteristics of effective $\mathrm{PD}$, and components of the situated learning model.

Observations were also conducted to determine how coordinators planned for and implemented PD. These included an 8-hr PD conference four coordinators collaboratively planned for elementary teachers in the region. A final observation occurred at the district office of one coordinator in which $5 \mathrm{hr}$ of one coordinator's work was observed. Observation field notes captured descriptions of the PD provided, interactions between the coordinator and others, and commentary provided by the coordinator about her thoughts and decision-making process. Aspects of the situated learning model and characteristics of effective PD were also noted. Transcription and initial analysis of field notes occurred within 2 days of the original observations.

\section{Data analysis}

Data from each coordinator's presurvey, postsurvey, and delayed post-SCA perceptions survey were analyzed using a repeated measures design in order to allow each coordinator to serve as his or her own control. An aggregate summed score of three survey items (Questions 2, 3, and 4), PBL (Questions 8, 9, and 10), and NOS (Questions 5, 6, and 7) was calculated for each coordinator. Other items analyzed included coordinators' perceptions of 
their ability to support high-quality research-based science instruction and to develop a strategic plan for their respective districts. The data were assumed to follow an additive model (i.e., scores for each coordinator were assumed to have the same trend over the three time points). Follow-up nonorthogonal simple contrasts were used to determine whether the scores received on the presurvey differed significantly from the scores received on the postsurveys and delayed postsurveys. Alpha slippage was controlled for through the use of a Bonferroni adjustment (i.e., both contrasts were evaluated at a per-comparison alpha rate of $.05 / 2=.025)$. To determine whether the $F$ statistics were properly distributed, we also assessed the homogeneity of difference in score variances (i.e., sphericity).

A two-step analytic induction approach was used to analyze the qualitative data (Erickson, 1986) in this interpretive study. First, all qualitative data were repeatedly read and holistically examined in order to inductively develop assertions. As part of this process definitions of inquiry, NOS, and PBL were assessed using a rubric for naïve, partial, or complete understanding. Seven initial assertions were generated through this process. The second data analysis step involved searching for confirming and disconfirming evidence to warrant the assertions. The initial assertions were revised in light of these data, resulting in three assertions well supported by the entirety of the data. Evidence to support these three assertions is presented in the form of quotes, vignettes, and observational notes. The generation and refining of assertions was completed through collaboration and discussion with a group of science educational researchers familiar with the context and data. This process improved the reliability of the findings .

Potential threats to the validity of the design were addressed throughout the study (Creswell \& Plano-Clark, 2011). During the data collection, qualitative and quantitative data were collected from the same population and contradictory results were explored. Multiple data sources were used in the study as suggested by Erickson (1986), including surveys, observations, and interviews.

\section{Results}

The purpose of this study was twofold. First, we sought to assess how science coordinators' understandings did or did not change following their participation in SCA. Second, we aimed to characterize the practices of coordinators and how these practices aligned or did not align with the goals of SCA. An overview of the quantitative results is presented first. These results are then integrated with three assertions related to coordinators' understandings and practices generated through analytic induction. Figure 4 depicts how the assertions are related to the research questions and summarizes each assertion. Then, in the sections that follow, each is discussed in detail with vignettes and supporting examples from the data.

\section{Changes following participation in SCA}

Results suggested that attending SCA improved coordinators' perceptions of their proficiency and understanding of their ability to develop PD for and to evaluate teachers' implementation of PBL, inquiry, and NOS. There were also improvements in their capacity to improve science instruction and to develop a strategic plan for science instruction. Furthermore, the results indicated that these improvements were maintained 

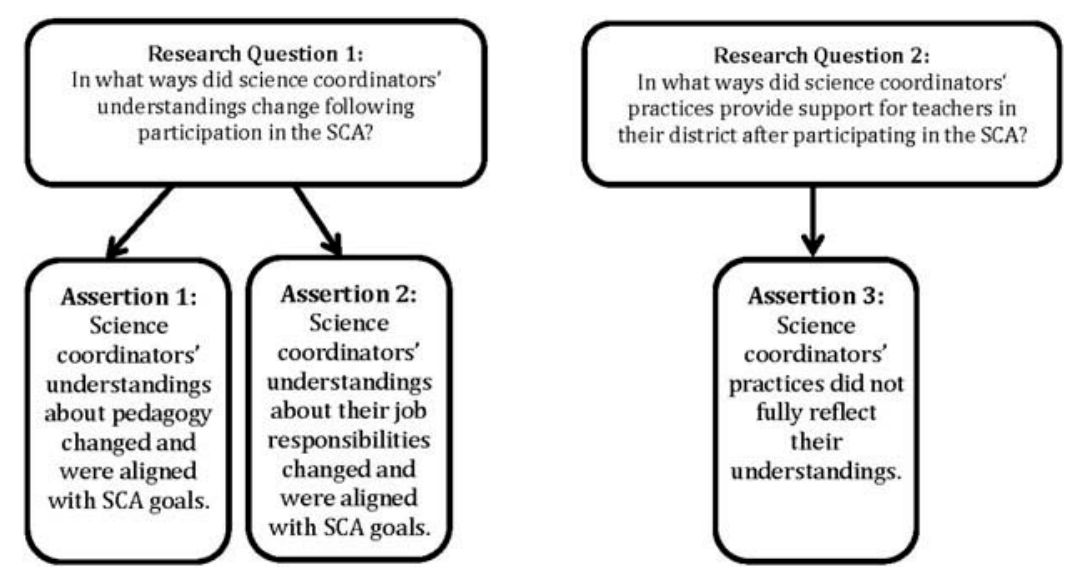

Figure 4. Relationship of the research questions to the assertions developed. SCA = Science Coordinator Academy.

Table 5. Changes in participants' proficiency and confidence on selected outcomes $(n=39)$.

\begin{tabular}{llcccc}
\hline Survey & $\begin{array}{c}\text { Supporting science } \\
\text { instruction }^{\mathrm{a}}\end{array}$ & Inquiry $^{\mathrm{b}}$ & $\begin{array}{c}\text { Nature of } \\
\text { science }^{\mathrm{b}}\end{array}$ & $\begin{array}{c}\text { Problem-based } \\
\text { learning }^{\mathrm{b}}\end{array}$ & $\begin{array}{c}\text { Strategic } \\
\text { planning }^{\mathrm{a}}\end{array}$ \\
\hline Pre & $3.15(1.01)$ & $9.33(3.12)$ & $8.14(2.49)$ & $8.87(2.93)$ & $2.38(1.09)$ \\
Post & $3.82(0.85)^{*}$ & $11.90(2.31)^{*}$ & $10.99(2.57)^{*}$ & $11.51(2.41)^{*}$ & $3.76(0.96)^{*}$ \\
Delayed post & $3.89(0.82)$ & $12.33(2.14)$ & $11.31(2.47)$ & $11.97(2.64)$ & $3.90(0.85)$ \\
\hline
\end{tabular}

Note. Data are $M(S D)$.

${ }^{\mathrm{a}}$ Indicates a scale from 1 to $5 .{ }^{\mathrm{b}}$ Indicates an aggregate score of three items with a total possible score of 5-15 points.

$* p<.001$.

a year following their attendance (see Table 5). These results are discussed in greater detail in relationship to the relevant assertions they support.

\section{Assertion 1: Science coordinators' understandings about pedagogy changed and were aligned with SCA goals}

SCA had three goals targeted at improving coordinators' understanding of and ability to identify and evaluate new types of pedagogy: (a) learning to make improvements in leadership, teacher learning, quality teaching, and student learning; (b) developing a common understanding of inquiry, NOS, and PBL; and (c) identifying aspects of effective science teaching and learning. As part of SCA, coordinators explored inquiry, NOS, and PBL definitions; participated in activities modeling these pedagogies; and discussed how to identify and evaluate these practices in the classroom (SCA Observations 2, 3, and 5). Coordinators' understandings about inquiry, NOS, and PBL improved and aligned with SCA goals after they participated. These changes are discussed in detail below.

Inquiry. Prior to attending SCA, coordinators had a wide range of definitions for inquiry. On the pre-SCA surveys some coordinators $(n=5 / 47)$ simply said "I don't know." Others, like James, defined inquiry as "teaching through having the students do hands-on activities where they learn the science concepts by activities reinforced with lecture, discussion, vocabulary, etc." Drake defined it as follows: "Inquiry instruction is a student centered 
strategy that allows the questions that the students generate to guide the lessons and activities." None of these definitions aligned with the definition used in SCA: "Students ask questions, collect, and analyze data and use evidence to solve problems." However, following SCA, the majority of coordinators' ( $n=41 / 44)$ definitions were improved, as exemplified by Chloe's definition: "Inquiry instruction allows students to develop questions and design experiments to test those ideas."

These results are further substantiated by the statistical results obtained for the items assessing coordinators' perceptions of their ability to identify, evaluate, and enhance teachers' science instruction. The mean score for coordinators' perceptions of their ability to identify, evaluate, and enhance teachers' inquiry instruction was statistically significant, $F(1.82,68.98)=38.61, p<.001$. Follow-up nonorthogonal contrasts evidenced a significant increase in scores from the presurvey $(M=9.33)$ to the postsurvey $(M=11.90), F(1$, $38)=14.75, p<.001$. However, there was no significant change from the postsurvey to the delayed postsurvey $(M=12.33), F(1,38)=2.28, p=.139 .^{1},{ }^{2}$

NOS. Prior to attending SCA, coordinators had varied definitions for NOS on the preSCA surveys. Some coordinators left the question blank $(n=6 / 47)$ or said "I don't know" $(n=7 / 47)$. Some $(n=15 / 47)$ appeared to have no prior experience with NOS and held a naïve understanding, as evidenced by Sierra's answer: "Not real sure what is being asked. I can guess that it is instruction where students are actively involved in the learning process." Still, others, like Matt, had partially aligned $(n=17 / 47)$ views: "A method used to develop ideas about the world by way of observing, thinking, experimenting, and validating." Only two $(n=2 / 47)$ had complete understandings of NOS prior to attending SCA.

The majority of coordinators $(n=36 / 44)$ had complete definitions of NOS following SCA (post-SCA surveys). After SCA, some coordinators $(n=8 / 44)$, like Brenda, still maintained a view of NOS that was naïve or partially aligned with the PD: "Science instruction involves many and layered levels of engagement between and among students and teacher/facilitator. There are opportunities for direct instruction, facilitation, openended, convergent, and problem solving. Inquiry is the driving force behind good science instruction." This response does not address the key tenets of NOS. However, those coordinators with a complete understanding following SCA were similar to Chloe, who stated,

NOS encompasses 7 key components dealing with what science is (and isn't) and what scientists do. Instruction should be interwoven into the content and not dealt with as a stand-alone. Teachers need to move away from "the" scientific method and need to emphasize the test ability and changing nature of scientific knowledge.

Significant differences between pre- and postsurvey items suggested that coordinators felt proficient and confident in identifying, evaluating, and enhancing NOS instruction. The mean score for coordinators' perceptions of their ability to identify, evaluate, and enhance teachers' NOS instruction was statistically significant, $F(2,76)=38.63, p<.001$. Follow-up nonorthogonal contrasts showed that there was a significant increase in scores from the presurvey $(M=8.14)$ to the postsurvey $(M=10.99), F(1,38)=46.70, p<.001$. However, there was not a significant change in scores from the postsurvey to the delayed postsurvey $(M=11.31), F(1,38)=0.757, p=.390$. This indicates that participants' understandings of 
NOS improved from the presurvey to the postsurvey and that these changes were maintained a year after their attendance. ${ }^{3,4}$

$P B L$. Before they attended SCA, coordinators' definitions of PBL on the pre-SCA surveys appeared to indicate partial understandings $(n=41 / 47)$ of the SCA definition: "Students solving a problem with multiple solutions like a scientist would in an authentic context, where both the problem and context are meaningful to students." Jossi's PBL definition was representative of how coordinators responded:

Problem-based learning is learning that takes place while investigating a problem related to a particular content area. It requires the learner to navigate through the scientific process while applying what was learned previously and discovering new knowledge in an effort to solve a real-world problem.

Another common answer was similar to Janet's response: "Problem based learning is where students learn content through solving problems. Investigating the application of the content in real world situations." After attending SCA, participants moved from partial understanding to a more complete understanding $(n=37 / 44)$ of PBL by being able to describe the planning process and goal of PBL in their definitions.

These results were supported further by the quantitative results. The difference between the mean scores for coordinators' perceptions of their ability to identify, evaluate, and enhance teachers' PBL instruction was statistically significant, $F(1.79,68.35)=29.66$, $p<$ .001. Follow-up nonorthogonal contrasts indicated that there was a significant increase in scores from the presurvey $(M=8.87)$ to the postsurvey $(M=11.51), F(1,38)=36.53$, $p<$ .001 . However, there were no significant changes in scores from the postsurvey to the delayed postsurvey $(M=11.97), F(1,38)=1.74, p=.195 .{ }^{5,6}$

\section{Assertion 2: Science coordinators' understandings about their job responsibilities changed and were aligned with SCA goals}

SCA had three goals targeted at improving coordinators' understanding about their job responsibilities: comparing district models of creating standards-based curriculum to support science instruction, investigating how to use data sources to improve district programs, and developing a science program strategic plan. As part of SCA, coordinators learned about and practiced aligning curriculum to support science instruction, practiced using data to inform PD and identify needs within their programs, and worked toward developing a strategic plan (SCA Observations 1, 2, 3, 4, and 5). Coordinators' understandings about using data and developing a strategic plan were improved after they attended SCA and are discussed in more detail below.

Supporting science instruction. As expected, prior to attending SCA, coordinators were confident in their understandings of and ability to support high-quality science instruction. Quantitative data supported these findings. The difference in the mean scores for coordinators' perceptions of their ability to support high-quality, research-based science instruction was statistically significant, $F(2,76)=14.18, p<.001$. Follow-up nonorthogonal contrasts indicated that there was a significant increase in scores from the presurvey $(M=3.15)$ to the postsurvey $(M=3.82), F(1,38)=14.75, p<.001$. However, there was no significant change from the postsurvey to the delayed postsurvey $(M=3.89), F(1,38)=$ 
$0.328, p=.570$. This suggests that coordinators perceived that their ability to support science instruction was improved by attending SCA and was maintained a year later. ${ }^{7}$

Using data to improve instruction. During SCA, implementers delivered instruction about various types of data coordinators could use to improve science instruction (SCA Observations 2, 3, and 5). Coordinators had multiple opportunities to practice analyzing data to evaluate teacher performance, investigate the alignment of the curriculum, and inform the design of their strategic plans. Coordinators identified this aspect of SCA as one of the most valuable. Coordinators appeared to understand the importance of using data to support science instruction, as also indicated in the statistical results.

The change in the mean scores for coordinators' perceptions of their ability to use data to improve instruction was found to be statistically significant, $F(2,76)=20.44, p<.001$. Follow-up nonorthogonal contrasts evidenced a significant increase in scores from the presurvey $(M=3.19)$ to the postsurvey $(M=4.10), F(1,38)=38.45, p<.001$. However, there was no significant change from the postsurvey to the delayed postsurvey $(M=4.02)$, $F(1,38)=0.268, p=.608 .^{8,9}$

Developing a strategic plan. Coordinators received instruction on and were provided with examples of how to develop a strategic plan during SCA (SCA Observations 3, 4, and 5). Coordinators worked on a rough draft and solicited feedback from peers and SCA leaders. Instruction on the development of a strategic plan resulted in coordinators understanding its necessity and taking steps to implement one (surveys and interviews).

The majority of coordinators discussed some aspect of a strategic plan when asked how they have used what they learned at SCA in surveys and interviews. For example, Diane wrote, "It has helped me understand the need for a division-level set of goals for science instruction." Marie answered, "The information shared has helped me strengthen some areas such as writing a strategic plan for my district." Another science coordinator, Bob, answered, "The model strategic plan: this way of thinking gave me a jumping-off point in developing a similar model within my own school district." When interviewed, Bob expanded on his survey response:

Being able to sit down with a sample strategic plan. One of the implementers brought a sample strategic plan from his work in a district so that we could use that as a jumping-off point.... We don't often have folks sitting and thinking about that level of strategy when thinking about the programs we offer. So just being able to have that and the model and other folks to collaborate with in terms of their ideas, what strategies they're taking on to meet their goals. I think that that was really powerful for me. (Delayed post-SCA interview)

Coordinators valued the instruction on strategic planning at SCA and understood its importance. The insight provided by implementers who had previously served as coordinators and the opportunity to collaborate and work with others aided coordinators in creating a strategic plan and understanding its importance. These responses suggest that cognitive apprenticeship, collaboration, active learning, coherence, and collective participation were perceived by coordinators as effective characteristics of SCA.

Statistical results from coordinators on strategic planning supported these qualitative results. The difference between the mean scores for coordinators' perceptions of their ability to develop a strategic plan for their respective districts was found to be statistically 
significant, $F(2,76)=50.74, p<.001 .^{10}$ Follow-up nonorthogonal contrasts indicated that there was a significant increase in scores from the presurvey $(M=2.38)$ to the postsurvey $(M=3.76), F(1,38)=51.44, p<.001$. However, there was no significant change in scores from the postsurvey to the delayed postsurvey $(M=3.90), F(1,38)=0.802, p=.376$. $^{11}$ The significant difference found in pre- to postsurvey scores for coordinators' perceptions of their ability to develop a strategic plan is evidence of coordinators' ability to put into practice what they learned. Furthermore, the statistical results revealed that there was no reversion from the postsurvey to the delayed postsurvey. This suggests not only that coordinators believed that strategic plans were important but also that this change was retained a year after the $\mathrm{PD}$.

\section{Assertion 3: Science coordinators' practices did not fully reflect their understandings}

Coordinators made improvements in inquiry, NOS, and PBL understandings; using data to improve instruction; and developing a strategic plan. However, their practices did not fully reflect their new understandings for all SCA goals. Coordinators' practices reflected their understandings of inquiry, using data to improve instruction, and developing a strategic plan. However, their practices did not fully reflect their understandings of NOS and PBL.

Inquiry. All coordinators valued the instruction on inquiry and mentioned it in surveys and interviews as one of the components they used with their teachers in PD. In her delayed postsurvey, Helen wrote the following:

I really liked learning about the definitions of inquiry vs. hands-on science vs. problem-based learning. We tend to use them as synonyms, but they are very different things. A good science program has components of all of these things, and the method of instruction should support the content.

This statement was representative of what coordinators wrote about the value of inquiry. Similarly, Ann indicated that she incorporated inquiry into her PD:

... inquiry was implemented with my teachers that when we had PD days this past year, in fact I called in, that's another benefit of the Academy, I called in Amy [academy instructor] to assist me presenting those two concepts... . Part of my strategy was to take that and make sure we all got on the same page as far as what those terms mean. And also hands-on science, teachers have a lot of misconceptions about what that meant as well. (Delayed post-SCA interview)

As a result of her participation in SCA, Ann developed and implemented PD focused on inquiry and hands-on instruction at the beginning of the school year. She also asked an SCA instructor to assist and provide her with support in implementing this PD. Ann's access to and utilization of help from a PD implementer demonstrates how ongoing coaching was invaluable in promoting positive outcomes.

Coordinators were first introduced to inquiry during SCA through discussions of why inquiry is such an important topic in science education. SCA implementers also introduced the levels of inquiry, and coordinators participated in a hands-on, inquiry activity called the Rusty Nail Lab (SCA Observation 2). Following this activity, coordinators discussed the need to scaffold inquiry for teachers and students and how they might do this type of PD for their teachers. Throughout SCA, inquiry was revisited and 
implementers emphasized how important inquiry is to increasing student engagement and achievement. The SCA approach to inquiry was highly contextualized and encouraged coordinators to think about how they would implement PD for their teachers. This may have contributed to the transfer of learning to practice that coordinators appeared to experience.

Furthermore, coordinators discussed how they utilized the resources provided by SCA to help implement PD for teachers. One representative example was described by Ken in his delayed postsurvey:

I used a lot of the strategies from the Academy. It was integrated in the PD workshops that were provided to all science teachers, both new and veteran. I also modified the PowerPoint ${ }^{\mathrm{tm}}$ materials [about inquiry] from the SCA and shared it with teachers and other administrators in our district. The handouts were very helpful, too. Those were given to new teachers.

Other coordinators had similar responses and found the resources provided by SCA to be helpful in providing instruction to teachers on inquiry. Also, the materials provided by SCA for inquiry were relevant and contextualized for how coordinators would use the materials. The use of these materials is further evidence of transfer of learning.

NOS. Coordinators' understandings of NOS improved after they attended SCA, but this was not fully reflected in their practices. NOS was not consistently mentioned as an area in which coordinators provided PD for teachers, nor was it observed. When Diane was asked about her intention to address NOS in her practice, she said, "Um, uh, I don't have that firmed up in my head on an approach for that" (post-SCA interview). Alex said, "Yeah, I think certainly with the curriculum changes coming. I mean, the state SOL [standards of learning] changes, but ours will be not next year, but the following year" (post-SCA interview). Alex was in the process of providing inquiry PD to his teachers and did not have an explicit plan for how he would implement NOS. This was representative of coordinators' response to implementing NOS. Many had the intention to implement NOS, but there was little evidence that it was actually being implemented.

During SCA, NOS was introduced through a card sort in which coordinators sorted statements about NOS and then discussed their piles with partners (SCA Observation 2). Implementers then introduced the tenets of NOS, how coordinators might evaluate NOS in the classroom, and the importance of instruction around NOS being explicit. SCA introduced the topic but did not contextualize the instruction on NOS for coordinators who would be delivering NOS PD. It may be that the resources and/or instruction for NOS were less relevant and contextualized. It may also be that inquiry was perceived as being a more pertinent topic to cover with teachers than NOS.

$P B L$. Similar to NOS, coordinators' understandings of PBL improved after they attended SCA, but this was not reflected in their practices. When asked about her experience with PBL at SCA, Lisa said, "I think that problem-based learning needed to be, actually talked about a lot more. I felt like that was just given cursory attention" (post-SCA interview). In general, coordinators did not mention PBL as an area in which they did PD for their teachers. Lisa's experience with the PBL session at SCA indicated the need for more time (duration) to be spent on this topic in order for coordinators to have a rationale for transferring this topic to their practice. 
PBL instruction during SCA began with coordinators participating in a Duck Lab (SCA Observation 2). This activity allowed coordinators to experience a shortened version of a PBL unit. Coordinators completed one activity and then discussed other supporting activities for the PBL unit. Coordinators also discussed the use of question maps and provided examples of past PBL units. The instruction on this topic did not provide coordinators with an authentic context in which to learn about how to provide PBL PD. Coordinators did not experience the whole unit, nor did they experience it as they might have used it in PD with teachers. This may have impacted coordinators' ability to transfer their PBL understandings to practice.

Using data to improve instruction. Results indicated that coordinators' understanding of using data to improve instruction improved after they attended SCA. These understandings were also reflected clearly in their practice. For example, Beth described using data to inform what type of PD she would offer and using state assessment data to inform benchmark assessments for the district. Ann explained how she was currently implementing what she had learned about using data in the district:

We've done a lot with the teacher evaluation process that's come up from the state and we're looking very closely at how to help teachers monitor student growth in their classroom. Instead of just making sure that they deliver the instruction but also how are those students growing as a result of your delivery ... we're actually gonna teach the teachers how to collect the data on their own students, where the greatest need is and move forward with that. (Delayed post-SCA interview)

Coordinators used data to inform their practice in a variety of ways: to inform PD needs, to design benchmark tests, to help teachers think about how to collect their own data for the teacher evaluation process, and to help schools identify science content areas in which they needed to grow. The contextualized nature of SCA and the opportunities for practice allowed coordinators to be able to transfer these understandings to their daily practice.

Developing a strategic plan. Coordinators had a clear understanding of the importance of developing a strategic plan after participating in SCA. Not only did coordinators value the time to work on strategic plans, they also continued developing and implementing them upon returning to their districts. When asked about her use of the strategic plan instruction from SCA on her delayed postsurvey Beth answered,

One of the things that we did, we really looked at our plan for science. We didn't have a solid plan in place-for any of the content areas-but, when I brought that information back one of my goals was to make sure that we had a science plan, a plan for science, a five-year plan. And currently we are in the middle of working on all of the different content at the same time.

Beth clearly identified the need for a 5-year strategic plan for science for her district and made it one of her personal goals to develop one. She also brought back to her district what she had learned about the process of developing a strategic plan to share with other content coordinators in her district and, at the time of the study, was in the process of developing the plan to be implemented. This suggested that coordinators were transferring what they learned at SCA to their practice within the district.

For example, all of the interviewed coordinators except Carrie were in the process of developing or implementing a strategic plan. The presence of a division-wide strategic 
plan under development in Carrie's district eliminated the need for her to develop her own strategic plan. However, it was evident that other coordinators valued and implemented the instruction on strategic planning in their practice.

\section{Discussion}

This study investigated the ways in which coordinators' understandings and practices changed following their participation in SCA. Coordinators' understandings and most of the targeted practices changed following participation in the $\mathrm{PD}$, and these changes were maintained a year after SCA. There were clear connections between the situated learning model and the incorporation of the characteristics of effective PD in SCA. Coordinators changed their understandings and most of the targeted practices, and these changes were maintained a year after SCA. The results of this study suggest that PD aligned with McLellan's (1996) model for situated learning may encourage the transfer of learning from PD to the practices of district coordinators.

Coordinators valued instruction on inquiry during SCA and understood that it was an appropriate method for teaching science. Furthermore, coordinators also transferred their learning to practice by implementing PD on inquiry within their districts. In PD coordinators provided to teachers, they emphasized inquiry, consistent with the goals and instruction of SCA. The active learning opportunities provided by SCA and the relevancy of the resources may have enhanced this transfer of learning. These findings suggest that providing instruction in multiple contexts and utilizing multiple, broad examples may facilitate the transfer of students' knowledge to new settings (Bransford et al., 2000). This extends previous research by applying it to adult learning transfer rather than student learning transfer (Bransford et al., 2000; Engle, Lam, Meyer, \& Nix, 2012).

These findings also support Perrine's (1984) finding that two of the most important components of the coordinator role are providing teachers with content and pedagogical supports and engaging in effective communication with teachers. However, more work is needed to understand how coordinators implemented PD for teachers. It is unclear whether PD was implemented exactly as it was presented in SCA or whether implementation was modified in some way. It is also unclear whether PD was implemented utilizing the characteristics of effective PD. During SCA, coordinators were provided with resources on how to do effective PD, but there was no explicit instruction around this topic. Thus, it may be unrealistic to expect coordinators to incorporate characteristics of effective PD into their own practice. Regardless, it is evident that coordinators implemented PD to educate teachers about inquiry aligned with SCA's inquiry definition.

In contrast to the way in which coordinators' practices fully reflected their understandings of inquiry, science coordinators' practices did not fully reflect their understandings of NOS and PBL. Coordinators did not appear to transfer their NOS and PBL understandings to practice. As evidenced by observations of SCA, it may be that PD around NOS and PBL was not contextualized enough for coordinators to transfer their understandings to practice. It is also possible that because it was not as contextualized, PD around these topics did not provide participants with an adequate rationale for integrating these abstract and complex pedagogies into their limited PD time with teachers. The implementers introduced these topics but did not contextualize how this type of PD might be implemented for teachers. 
These findings suggest that there may not have been a sufficient mixture of general principles and specific examples in the PD (Bransford et al., 2000).

Furthermore, these results may suggest the need for there to be more time spent on these topics during SCA in order for transfer to occur. During SCA, very little time was spent on NOS and PBL; thus, more in-depth time on the topic may have allowed the implementers to contextualize these topics more effectively for coordinators. In addition, SCA did not take a process skills-based approach to teaching NOS as suggested by Matkins and Bell (2007) and Mulvey (2012). Utilizing a process skills-based approach with in-service teachers, Mulvey found that teachers substantially improved their NOS understandings and, more important, were teaching NOS regularly in their classrooms. It may be that using a more process skills-based approach to NOS PD sessions facilitates changes in science coordinator practices around this topic.

SCA provided a social context for coordinators to engage in active learning with a clear content focus and to develop and create a product directly related to their everyday practice. Coordinators had opportunities to analyze data and collaborate on their strategic plans with other coordinators on multiple occasions and to receive feedback from instructors. The evidence clearly indicated that as a result of these practices coordinators understood the importance of a strategic plan and changed their practices by developing and/or implementing one. Results also indicated that coordinators used data to improve science instruction and to guide the content of their strategic plans. This suggests that including active learning (Garet et al., 2001), a content focus (Birman, Desimone, Porter, \& Garet, 2000; Cohen \& Hill, 1998; Kennedy, 1999), and collaboration (Birman et al., 2000; Borko, 2004) in PD may be important for affecting changes in coordinators' practices.

The incorporation of two situated learning components, collaboration and an authentic context, into SCA appears to have had the greatest bearing on whether coordinators transferred their learning to practice. Similarly, Bell, Maeng, and Binns (2013) identified collaboration and an authentic context as key components in supporting preservice teachers in integrating technology. Bell, Maeng, and Binns (2013) also suggested cognitive apprenticeship, coaching, and multiple opportunities for practice as important in preparing preservice science teachers for technology use. These components were also integrated into SCA; however, coordinators did not appear to benefit from these components as much as the preservice teachers. Coordinators, in contrast to preservice teachers, have more knowledge and teaching and learning experience; thus, the need for cognitive apprenticeship, coaching, and multiple opportunities for practice during PD may be less than for preservice teachers. The specific components of situated learning important in the transfer of learning as a result of PD may vary depending on the audience.

\section{Implications}

To our knowledge, this is the first study investigating how science coordinators are supported and how they in turn support teachers in PD following a PD program designed specifically for science coordinators. The emphasis placed on an authentic learning environment within a social context, as aligned with situated learning, by SCA promoted changes in the understandings and some practices of coordinators. This indicates that the relationship between the situated learning model, characteristics of effective $\mathrm{PD}$, and the activities of SCA may be appropriate in designing PD for coordinators. The present study 
also extends previous investigations (Madrazo \& Hounshell, 1987; Perrine, 1984; Tracy, 1993) in that it provides a clearer picture of the types of support coordinators provide to teachers as well as the methods coordinators use to provide that support.

These results warrant further study to determine how well aligned science coordinators' implementation of PD for teachers is with SCA's goals and instruction and with characteristics of effective PD. If coordinators implement PD that does not incorporate aspects of effective PD, then changes in teacher learning, classroom practices, and student achievement may not be evident, as suggested by Desimone (2009) and Firestone et al. (2005). These results plainly point to how difficult and complex it is to implement effective $\mathrm{PD}$ to improve individuals' understandings and practice, let alone improve teacher and student understandings. Although SCA improved coordinators' understandings, their subsequent practices did not fully reflect their understandings. Ideally, we would expect coordinators' practices to then impact teacher understandings and practices, but realistically there will also be barriers. The complicated nature of PD depicted in Figure 1 indicates the importance of studying all layers of PD. Future research should focus on gaining a deeper understanding of these mediating factors and seek out how to keep these factors from becoming barriers.

Although Goldberg (1970) advocated the need for science supervisors to be educated and trained and suggested a formal program, few formal or informal educational opportunities for coordinators exist today. SCA is one of the few, if not only, opportunities designed specifically for new coordinators. It provided situated PD and was characterized by components of effective PD. Specifically, it incorporated collaborative, social, contextualized, authentic, active learning experiences with a clear content focus in order to facilitate the transfer of learning to practice following PD. The effective model of PD for science coordinators explored in this study is one that states and districts can emulate to support their supporters.

\section{Notes}

1. Mauchly's chi-square approximation revealed that sphericity was violated, $\chi^{2}(2)=6.02, p=$ .049. Therefore, degrees of freedom were corrected using Huynh-Feldt estimates of sphericity $(\varepsilon=.91)$. Tukey's test of additivity was violated, $F(2,75)=7.85, p=.006$.

2. Omega squared indicated that $34 \%$ of the variance in scores for inquiry was attributable to the times when scores were evaluated, which suggests that coordinators believed that inquiry was an appropriate method of teaching science and maintained this belief a year later.

3. Mauchly's chi-square approximation confirmed that sphericity was obtained, $\chi^{2}(2)=0.980, p$ $=.68$. Tukey's test of additivity revealed that the data followed an additive model, $F(2,75)=$ $0.147, p=.70$.

4. Omega squared indicated that $36 \%$ of the variance in coordinators' scores for NOS was attributable to the timing of the surveys.

5. For PBL, Mauchly's chi-square approximation revealed that sphericity was violated, $\chi^{2}(2)=$ $6.45, p=.040$. Therefore, degrees of freedom were corrected using Huynh-Feldt estimates of sphericity $(\varepsilon=.90)$. Tukey's test of additivity confirmed that the data followed an additive model, $F(2,75)=0.272, p=.60$.

6. Omega squared showed that $31 \%$ of the variance in the scores for PBL was attributable to the time when the scores were evaluated.

7. Mauchly's chi-square approximation confirmed sphericity, $\chi^{2}(2)=3.46, p=.18$. Tukey's test of additivity revealed that the data followed an additive model, $F(2,75)=1.3, p=.27$. 
8. Omega squared showed that $25 \%$ of the variance in the scores for using data to improve instruction was attributable to the timing of the surveys, which suggests that coordinators understood how this was important to their job responsibilities and that this was maintained a year later.

9. Mauchly's chi-square approximation confirmed that sphericity was obtained, $\chi^{2}(2)=2.38, p=$ .30. Tukey's test of additivity was violated, $F(2,75)=4.25, p=.04$.

10. Mauchly's chi-square approximation revealed that sphericity was obtained, $\chi^{2}(2)=5.09, p=$ .08 . Tukey's test of additivity evidenced that the data followed an additive model, $F(1,75)=$ $1.04, p=.31$.

11. Omega squared showed that $45 \%$ of the variance in the scores for strategic planning was attributable to the timing of the surveys.

\section{Funding}

This research was supported by funding from the U.S. Department of Education Investing in Innovation grant program. However, the results presented here do not necessarily represent the policy of the U.S. Department of Education, and readers should not assume endorsement by the federal government.

\section{ORCID}

Brooke A. Whitworth (10 http://orcid.org/0000-0002-3944-291X

Jennifer L. Maeng (10) http://orcid.org/0000-0003-4955-4023

\section{References}

Abd-El-Khalick, F. S., Bell, R. L., \& Lederman, N. G. (1998). The nature of science and instructional practice: Making the unnatural natural. Science Education, 82, 417-436.

Akerson, V. L., \& Abd-El-Khalick, F. (2003). Teaching elements of nature of science: A yearlong case study of a fourth-grade teacher. Journal of Research in Science Teaching, 40, 1025-1049. doi:10.1002/(ISSN)1098-2736

Akerson, V., \& Hanuscin, D. (2007). Teaching nature of science through inquiry: Results of a threeyear professional development program. Journal of Research in Science Teaching, 44, 653-680. doi:10.1002/tea.20159

Akerson, V. L., Morrison, J. A., \& McDuffie, A. R. (2006). One course is not enough: Preservice elementary teachers' retention of improved views of nature of science. Journal of Research in Science Teaching, 43, 194-213. doi:10.1002/(ISSN)1098-2736

Anderson, R. D. (2002). Reforming science teaching: What research says about inquiry. Journal of Science Teacher Education, 13, 1-12. doi:10.1023/A:1015171124982

Beinsenherz, P. C., \& Yager, R. E. (1991). The school science supervisor: A necessity for a quality program. School of Science and Mathematics, 91, 152-156. doi:10.1111/j.1949-8594.1991.tb12069.x

Bell, R. L., Lederman, N. G., \& Abd-El-Khalick, F. S. (2000). Developing and acting upon one's conception of the nature of science: A follow-up study. Journal of Research in Science Teaching, 37, 563-581.

Bell, R. L., Maeng, J. L., \& Binns, I. C. (2013). Learning in context: Technology integration in a teacher preparation program informed by situated learning theory. Journal of Research in Science Teaching, 50, 348-379.

Bell, R., Smetana, L., \& Binns, I. (2005). Simplifying inquiry instruction: Assessing the inquiry level of classroom activities. The Science Teacher, 72(7), 30-33.

Birman, B. S., Desimone, L., Porter, A. C., \& Garet, M. S. (2000). Designing professional development that works. Educational Leadership, 57(8), 28-33. 
Birman, B., Le Floch, K. C., Klekotka, A., Ludwig, M., Taylor, J., Walters, K., ... Yoon, K. (2007). State and local implementation of the No Child Left Behind Act: Vol. 2. Teacher quality under NCLB: Interim report. Washington, DC: U.S. Department of Education; Office of Planning, Evaluation and Policy Development; Policy and Program Studies Service.

Borko, H. (2004). Professional development and teacher learning: Mapping the terrain. Educational Researcher, 33(8), 3-15. doi:10.3102/0013189X033008003

Bransford, J. D., Brown, A. L., \& Cocking, R. R. (Eds.). (2000). How people learn: Brain, mind, experience, and school. Washington, DC: National Academies Press.

Bybee, R. (1997). Achieving scientific literacy: From purposes to practices. Portsmouth, NH: Heinemann.

Cohen, D. K., \& Hill, H. C. (1998). Instructional policy and classroom performance: The mathematics reform in California (RR-39). Philadelphia, PA: Consortium for Policy Research in Education.

Copeland, M. A., \& Knapp, M. S. (2006). Connecting leadership with learning: A framework for reflection, planning and action. Alexandria, VA: Association for Supervision and Curriculum Development.

Corcoran, T., Fuhrman, S. H., \& Belcher, C. L. (2001). The district role in instructional improvement. Phi Delta Kappan, 83(1), 78-84. doi:10.1177/003172170108300116

Creswell, J. W., \& Plano-Clark, V. L. (2011). Designing and conducting mixed methods research (2nd ed.). Thousand Oaks, CA: Sage.

Desimone, L. M. (2009). Improving impact studies of teachers' professional development: Toward better conceptualizations and measures. Educational Researcher, 38, 181-199. doi:10.3102/ 0013189X08331140

Domina, T., Lewis, R., Agarwal, P., \& Hanselman, P. (2015). Professional sense-makers: Instructional specialists in contemporary schooling. Educational Researcher, 44, 359-364. doi:10.3102/0013189X15601644

Duschl, R. A., Schweingruber, H. A., \& Shouse, A. W. (Eds.). (2007). Taking science to school: Learning and teaching science in grades K-8. Washington, DC: National Academies Press.

Edmondson, M. E., Sterling, D., \& Reid, V. (2012, March). Investigating the impact of a new science coordinator/liaison academy. Paper presented at the annual meeting of the National Association of Research in Science Teaching, Indianapolis, IN.

Engle, R. A., Lam, D. P., Meyer, X. S., \& Nix, S. E. (2012). How does expansive framing promote transfer? Several proposed explanations and a research agenda for investigating them. Educational Psychologist, 47, 215-231. doi:10.1080/00461520.2012.695678

Erickson, F. (1986). Qualitative methods in research on teaching. In M. Wittrock (Ed.), Handbook of research on teaching (3rd ed., pp. 119-161). New York, NY: Macmillan.

Ertmer, P. A., Glazewski, K. D., Jones, D., Ottenbreit-Leftwich, A., Goktas, Y., Collins, K., \& Kocaman, A. (2009). Facilitating technology-enhanced problem-based learning (PBL) in the middle school classroom: An examination of how and why teachers adapt. Journal of Interactive Learning Research, 20(1), 35-54.

Firestone, W. A., Mangin, M. M., Martinez, M. C., \& Plovsky, T. (2005). Leading coherent professional development: A comparison of three districts. Educational Administration Quarterly, 41, 413-448. doi:10.1177/0013161X04269605

Fryckholm, J. (2004). Teachers' tolerance for discomfort: Implications for curricular reform in mathematics. Journal of Curriculum and Supervision, 19, 125-149.

Garet, M. S., Porter, A. C., Desimone, L., Birman, B. F., \& Yoon, K. S. (2001). What makes professional development effective? Results from a national sample of teachers. American Educational Research Journal, 38, 915-945. doi:10.3102/00028312038004915

Goldberg, H. P. (1970). The education of the science supervisor. School of Science and Mathematics, 70, 363-365. doi:10.1111/j.1949-8594.1970.tb08646.x

Hewson, P. W. (2007). Teacher professional development in science. In S. K. Abell \& N. G. Lederman (Eds.), Handbook of research on science education (pp. 1177-1202). Mahwah, NJ: Erlbaum.

Hmelo-Silver, C. E. (2004). Problem-based learning: What and how do students learn? Educational Psychology Review, 16, 235-266. doi:10.1023/B:EDPR.0000034022.16470.f3 
Honig, M. I. (2006). Street-level bureaucracy revisited: Frontline district central office administrators as boundary spanners in education policy implementation. Educational Evaluation and Policy Analysis, 28(4), 357-383. doi:10.3102/01623737028004357

Kennedy, M. M. (1999). Form and substance in mathematics and science professional development. Madison: University of Wisconsin at Madison, National Institute for Science Education.

Kennedy, M. M. (2016). How does professional development improve teaching? Review of Educational Research, 86, 945-980. doi:10.3102/0034654315626800

Keys, C. W., \& Bryan, L. A. (2001). Co-constructing inquiry-based science with teachers: Essential research for lasting reform. Journal of Research in Science Teaching, 38, 631-645. doi:10.1002/ (ISSN)1098-2736

Lederman, N. G. (2007). Nature of science: Past, present, and future. In S. K. Abell \& N. G. Lederman (Eds.), Handbook of research on science education (pp. 831-880). Mahwah, NJ: Erlbaum.

Lipsky, M. (1983). Street-level bureaucracy: The dilemmas of the individual in public service. New York, NY: Russell Sage Foundation.

Loucks-Horsley, S., Stiles, K. E., Mundry, S., Love, N., \& Hewson, P. W. (2010). Designing professional development for teachers of science and mathematics (3rd ed.). Thousand Oaks, CA: Corwin Press.

Luft, J., Bell, R. L., \& Gess-Newsome, J. (Eds.) (2008). Science as inquiry in the secondary setting. Arlington, VA: National Science Teachers Association Press.

Luft, J. A., \& Hewson, P. W. (2014). Research on teacher professional development programs in science. In S. K. Abell \& N. G. Lederman (Eds.), Handbook of research on science education (2nd ed., 889-910). Mahwah, NJ: Erlbaum.

Madrazo, G. M., \& Hounshell, P. B. (1987). Science supervisor: Results of research in science supervision. Science Education, 71(1), 9-14. doi:10.1002/sce.3730710104

Matkins, J. J., \& Bell, R. L. (2007). Awakening the scientist inside: Global climate change and the nature of science in an elementary science methods course. Journal of Science Teacher Education, $18,137-163$.

McLellan, H. (1996). Situated learning: Multiple perspectives. In H. McLellan (Ed.), Situated learning perspectives (pp. 5-17). Englewood Cliffs, NJ: Educational Technology.

Mulvey, B. (2012). Learning and teaching about the nature of science through process skills (Doctoral dissertation). Retrieved from https://search.proquest.com/openview/ b3431d2c608970b580ab91c447c255cc/1?pq-origsite = gscholar\&cbl=18750\&diss=y

National Commission on Mathematics and Science Teaching for the 21st Century. (2000). Before it's too late. Washington, DC: U.S. Department of Education.

National Research Council. (1996). National science education standards. Washington, DC: National Academies Press.

National Research Council. (2012). A framework for K-12 science education: Practices, crosscutting concepts, and core ideas. Washington, DC: National Academies Press.

NGSS Lead States. (2013). Next generation science standards: For states, by states. Washington, DC: National Academies Press.

Perrine, W. G. (1984). Teacher and supervisory perceptions of elementary science supervisors. Science Education, 68, 3-9. doi:10.1002/sce.3730680104

Peters, E. E. (2009). Shifting to a student-centered science classroom: An exploration of teacher and student changes in perceptions and practices. Journal of Science Teacher Educationm. Advance online publication. doi:10.1007/s10972-009-9178-z

Pianta, R. C. (2011). Teaching children well: New evidence based approaches to teacher professional development and training. Center for American Progress, 11, 1-36.

Reinisch, B. (1966). The need for science consultants. Science Education, 50, 52-54. doi:10.1002/ (ISSN)1098-237X

Rogers, M. P., Abell, S., Lannin, J., Wang, C., Musikul, K., Barker, D., \& Dingman, S. (2007). Effective professional development in science and mathematics education: Teachers' and facilitators' views. International Journal of Science and Mathematics Education, 5, 507-532. doi:10.1007/s10763-006-9053-8 
Stepien, W., \& Gallagher, S. (1993). Problem based learning: As authentic as it gets. Educational Leadership, 50, 25-28.

Sterling, D. R. (2007). Modeling problem-based instruction. Science and Children, 45(4), 50-53.

Sterling, D. R., \& Frazier, W. M. (2006). Collaboration with community partners. The Science Teacher, 73(4), 28-31.

Sterling, D. R., Matkins, J. J., Frazier, W. M., \& Logerwell, M. G. (2007). Science camp as a transformative experience for students, parents, and teachers in an urban setting. School Science and Mathematics, 107, 134-148. doi:10.1111/j.1949-8594.2007.tb17928.x

Tracy, S. J. (1993). The overlooked position of subject area supervisor. Clearing House, 67(1), 25-30. doi:10.1080/00098655.1993.9956011

Trumbull, D. J., Scrano, G., \& Bonney, R. (2006). The relations among two teachers' practices and beliefs, conceptualizations of the nature of science, and their implementation of student independent inquiry projects. International Journal of Science Education, 28, 1717-1750. doi:10.1080/ 09500690600560928

Tsai, C. C. (2002). Nested epistemologies: Science teachers' beliefs of teaching, learning, and science. International Journal of Science Education, 24, 771-783. doi:10.1080/09500690110049132

Whitworth, B. A. (2014). Professional development and teacher change: The missing leadership link. (Doctoral dissertation).

Whitworth, B. A., \& Chiu, J. L. (2015). Professional development and teacher change: The missing leadership link. Journal of Science Teacher Education, 26, 121-137. doi: 10.1007/s10972-014-94112

Whitworth, B. A., Maeng, J. L., Wheeler, L. B., \& Chiu, J. L. (2017). Investigating the role of a district science coordinator. Journal of Research in Science Teaching, 54, 914-936. doi: 10.1002/ tea. 21391

Wilson, S. M. (2013, April 19). Professional development for science teachers. Science, 340, 310-313. doi:10.1126/science.1230725

Yoon, K. S., Duncan, T., Lee, S. W.-Y., Scarloss, B., \& Shapley, K. (2007). Reviewing the evidence on how teacher professional development affects student achievement (Issues \& Answers Report, REL 2007-No. 033). Washington, DC: U.S. Department of Education, Institute of Education Sciences, National Center for Education Evaluation and Regional Assistance, Regional Educational Laboratory Southwest. 